\title{
Blinding the Elephant: Combat, Information, and Rebel Violence
}

\section{Helge Holtermann}

Department of Political Science, University of Oslo, Oslo, Norway

\author{
Post-print version of an article published in Terrorism and Political \\ Violence. Please use the following citation: \\ Helge Holtermann (2019) Blinding the Elephant: Combat, Information, and Rebel \\ Violence, Terrorism and Political Violence, DOI: 10.1080/09546553.2019.1630383.
}

\begin{abstract}
How does combat affect insurgent violence against civilians? Existing studies emphasize the role of combat outcomes, but have not explored the direct effects of various combat events. This article argues that one such event, government attacks on the rebels, has a positive effect on insurgent violence that stems from the logic of guerrilla warfare. In guerrilla wars, government forces tend to rely on informants in finding the insurgents. Their attacks therefore often evince civilian denunciation. To deter future denunciations, the rebels have incentives to subsequently punish the suspected or known denunciator. This argument is probed using detailed original data from Nepal's Maoist insurgency. A panel analysis shows that government attacks were positively associated with rebel violence against civilians, and especially with violence against suspected informants. Process-tracing evidence further supports the argument, suggesting that the rebels used violence strategically to prevent information leaks and government attacks.
\end{abstract}




\section{Introduction}

During insurgencies, areas heavily afflicted by rebel violence one year may be largely spared from it the next year, and vice versa. In Peru's Ayacucho province, the Shining Path's killings peaked in 1984, and then steeply declined there while increasing in other provinces. ${ }^{1}$ In Afghanistan, Taliban violence against civilians was heavily concentrated in the south in the mid-2000s, but became more evenly spread across the country's regions over the next decade. $^{2}$ And in Nepal's Maoist conflict, the epicenter of rebel violence shifted from the midwestern hills in the initial period toward the central and western plains in the last few years. ${ }^{3}$ Why do we see such spatiotemporal shifts in rebel violence?

Existing research provides some hypotheses, but no definitive answers. Many studies of violence in civil war focus on explaining variation in lethality across conflicts, rebel organizations, or locations. ${ }^{4}$ Within the smaller body of literature looking at temporal dynamics, it is commonly claimed that violence against civilians is related to military dynamics. One theory emphasizes the role of territorial control, predicting that armed actors will kill more civilians where and when they have local dominance. ${ }^{5}$ Other studies suggest that combat matters through its physical effects: when losing on the battlefield, rebels increasingly harm civilians, they argue, because losses push them toward a terrorist strategy, ${ }^{6}$ or toward predatory and abusive behavior. ${ }^{7}$

While these studies offer important insights, they overlook a more direct link between combat and violence, which emanates from the logic of guerrilla warfare. A key trait of such warfare is that the rebels seek to avoid defensive battles. Rather than defend positions, they mostly hide in small units. In most contexts, government forces can therefore hardly locate the rebels without the aid of local civilian informants. Consequently, when the rebels are attacked by government forces, they often know or suspect that someone informed on them. To prevent future informing, the rebels are subsequently likely to punish the informant. 
Government attacks may therefore spur rebel violence not only through their material effects, but also by conveying information that induces attacks on suspected informants.

I probe this argument in a mixed-methods analysis of the Maoist insurgency in Nepal from 1996 to 2006. First, I conduct a panel analysis using a detailed, new event dataset, which allows for distinguishing between different types of combat events, their outcomes, and whether the victim was accused of informing. Next, I assess qualitative implications of the argument through process tracing, drawing upon elite interviews and existing local-level studies.

The analysis provides much support for the informational argument. Most importantly, government attacks were associated with more rebel violence against civilians in general, and against suspected informants in particular. The analysis is also consistent with the existing finding that combat often sparks rebel violence. However, it suggests that not all forms of combat are equally related to violence, and indicates that rebel incentives to deter informing is a key mechanism. More broadly, it suggests that insurgent violence can be better understood through the lens of guerrilla warfare than through the lenses of predation or terrorism.

I next discuss existing theories linking combat to rebel violence, before I present the informational argument and derive testable hypotheses. The empirical section begins with a description of the design and data and proceeds with the quantitative and qualitative analyses. In the conclusion, I discuss the scope and implications of the argument in light of the evidence.

\section{Combat and Rebel Violence: Existing Arguments}

Combat can have two possible effects: First, it can influence the belligerents' capabilities and territorial control through the killing of combatants or leaders and the capture of armaments 
and bases. Second, it can convey information about military capabilities and the behavior of civilians. ${ }^{8}$ Most existing studies focus on the first type of effect, emphasizing the role of rebel losses and shifts in territorial control.

\section{Losses and Violence}

Combat may obviously affect rebel violence by reducing the rebels' capacity. Losses could on one hand have a negative effect by making the rebels less able to harm civilians. This would be the case if the government entirely wiped out or cleared the rebels from inhabited areas. 9 However, these outcomes appear to be rare, and often depend on other efforts than combat. Moreover, targeting civilians does not require great military capability. Even a weakened rebel force may therefore cause much harm. ${ }^{10}$ Existing evidence also supports these counterarguments: Rebel combat losses tend to be associated with more, rather than less, rebel violence against civilians. ${ }^{11}$

One explanation could be that losses create predatory incentives: After losing cadres, rebels must increase their demands upon local civilians to refill their ranks. Simultaneously, losses make civilians less willing to join by indicating that life as a rebel is dangerous. As the supply of volunteers fails to match rebel demand, rebels may turn to predation, such as taking recruits by force and killing those who resist. ${ }^{12}$

Losses might also be linked to violence through tactical substitution. ${ }^{13}$ According to this argument, violence against civilians serves the same purpose as attacks on military forces do: to impose costs on the government. When rebels suffer losses and their military prospects fall, they may therefore be pushed to shift their efforts from military attacks to attacks on soft targets. ${ }^{14}$

Both accounts may be challenged, however. Killing local people to hurt the government or to get new recruits would probably make the rebels unpopular and could spark 
local resistance or increased backing for the counterinsurgency. ${ }^{15}$ It is therefore unclear whether predatory or terroristic violence is a rational response to losses. Furthermore, in contradiction of these arguments, existing research does not clearly suggest that weaker rebels employ more violence against civilians. ${ }^{16}$

Another argument holds that the loss of rebel leaders could weaken organizational cohesion and control, thereby producing more abusive, predatory, and vengeful violence by rebel combatants. ${ }^{17}$ While this appears plausible, successful decapitation strikes on rebel groups tend to be rare, which may suggest that such strikes are unlikely to explain much of the variation in rebel violence across time and space within a conflict.

\section{Control and Violence}

Combat could also affect rebel violence by shifting patterns of local military control. According to Kalyvas' influential control-collaboration theory, selective violence is used by both rebel and government forces to deter civilian collaboration with the enemy (“defection"). ${ }^{18}$ Control plays a critical role, because it shapes civilians' incentives to defect as well as their incentives to denunciate defectors. Defections are expected in all situations, except when one actor wields full control. But since people fear counter-denunciations, they should denunciate only to the most powerful actor in the area. The belligerents are therefore expected to use the most violence where they are locally dominant. In contrast to the predation and substitution arguments, this theory thus suggests that after successfully battling the government in an area, the rebels would kill more people. 


\section{Informing, Government Attacks, and Rebel Violence}

Control-collaboration theory helps elucidate the role of civilian informants in the production of violence. However, it does not fully capture how informing matters for violence against civilians. Belligerents do not aim only at maximizing control and civilian collaboration: They also seek to kill the opponents' forces and avoid being killed themselves. In irregular wars, civilians play a vital role in obtaining these objectives because insurgents, unlike government forces, tend to hide and avoid defensive battles. ${ }^{19}$ Counterinsurgents therefore depend on civilian informants not only to expose civilian defectors, but also to find and attack rebel combatants. $^{20}$

Such attacks tend to end badly for the rebels, since they mostly operate in small, lightly armed units. They therefore worry much about informing. Che Guevara, for instance, advised guerrillas to live in secrecy for a lengthy period, "[...] since it would be dangerous to trust any neighbor whose fidelity is not perfectly established." ${ }^{21}$ His concern would prove well founded: Bolivian forces eventually captured him with the help of a local informant. ${ }^{22}$

To avoid such a fate, insurgents tend to punish informing harshly. Even Che Guevara, who opposed terrorist tactics, would execute informants. ${ }^{23}$ Many other guerrilla leaders with various ideological leanings, such as Mao Zedong, ${ }^{24}$ Vo Nguyen Giap, ${ }^{25}$ Mullah Omar, ${ }^{26}$ and George Grivas, ${ }^{27}$ have espoused similar measures against government collaborators.

To punish informing, however, the rebels often depend on civilians to denounce government informants. Following control-collaboration theory, civilians should be deterred from doing so in government-controlled areas. However, civilian collaboration does not depend only on control. Social ties and political support also encourage collaboration through various mechanisms, including solidarity and social incentives. ${ }^{28}$ Importantly, these factors tend to favor the insurgents, because they, unlike the government, choose where to go. 
Furthermore, even where they lack control, insurgents may forge clandestine local institutions, such as militias and political organizations, that foster collaboration. ${ }^{29}$

If attacked by government forces, insurgents should therefore often receive information about who informed on them. ${ }^{30}$ Consequently, government attacks should tend to trigger rebel punishment of suspected or known informants. This argument yields the following prediction:

H1: Government attacks against insurgents make insurgent violence against civilians more likely.

Further, the argument gives a more specific implication about the targets of insurgent violence:

H2: Government attacks are more strongly associated with insurgent violence against accused informants than with insurgent violence against other civilians.

\section{Contingencies}

The argument may not apply equally in all wartime contexts. Since the rebels are assumed to be hiding, the argument should apply only to asymmetric conflicts. Within such conflicts, other conditions might also moderate the link between government attacks and rebel violence:

First, state forces' reliance on civilian informants for attacking the rebels may vary. Where the state is highly capable, they might rely more on direct surveillance or rebel defectors to find the rebels. ${ }^{31}$ Furthermore, in areas under rebel control, the government might rely less on informants, since the rebels may operate more openly and civilians should be less 
willing to inform. Consequently, the association between government attacks and rebel violence against suspected informants may be weaker under these conditions.

The rebels' ability to identify and punish government informants may also vary. First, it could be lower in government-controlled areas, where civilians may be afraid to speak with the rebels and the rebels may lack the capacity to punish informants. ${ }^{32}$ Second, identifying informants is likely to be more difficult in urban settings, where dense population and modern communications can help protect informants' anonymity. ${ }^{33}$ Under both these conditions, the relationship between government attacks and rebel violence may therefore be weaker.

In sum, the informational mechanism linking government attacks to rebel violence should be most salient in rural, contested areas during asymmetric conflicts involving a relatively weak state. Notably, all these conditions are typical for civil wars, which suggests that the argument has a wide scope. ${ }^{34}$

\section{Design and Data}

I probe the argument in a case study of the Maoist insurgency in Nepal. The Nepalese Maoists emerged from a parliamentary party and took up arms in February 1996. While small to begin with, their insurgency would spread and cause a national crisis that eventually ended in a negotiated settlement ten years later. ${ }^{35}$ In the process, more than thirteen thousand people were killed, including at least five thousand civilians. ${ }^{36}$

I employ a mixed-methods approach to analyze the killings carried out by the rebels. I first assess the hypotheses in a panel analysis, using new event data. Subsequently, I use process tracing to help identify the causal mechanisms in operation. 


\section{Why Nepal?}

The Nepalese conflict is exceptionally well suited for assessing the argument. Importantly, it meets the scope condition of asymmetry: throughout the conflict, the rebels were militarily weaker than the government and relied predominantly on guerrilla warfare ${ }^{37}$. The case also features a great amount of spatiotemporal variation in combat and violence, which gives power to the statistical analysis. ${ }^{38}$

Furthermore, we have rich data for the conflict. Assessing the hypotheses not the least requires data on whether the victim was accused of informing. Such data are provided by Joshi and Pyakurel's ${ }^{39}$ rarely detailed dataset on victims from the Maoist conflict, based on documentation by the Informal Sector Service Center (INSEC). ${ }^{40}$ With representatives in all districts during the conflict, INSEC worked to document every violent incident through local interviews and written sources. The systematic, local documentation process not only makes the data more reliable; it also guards against common selection biases in media-based datasets. Guarding against such biases is especially important in this study because violence against informants, which typically involve a single victim in rural areas, are the kinds of events that often go unreported. ${ }^{41}$

\section{Central Variables}

The analysis also calls for detailed data on combat events, including information about their initiator and outcome. ${ }^{42}$ To provide a suitable conflict events dataset, I reconstruct and expand the Joshi-Pyakurel victim data. First, I link victims killed in the same incident. For violence outside combat, victims are connected to the same event if they were killed in the same ward, on the same date, and by the same actor. ${ }^{43}$ For combat events, I additionally consult the event descriptions in INSEC's online victim database. ${ }^{44}$ When this did not provide sufficient 
information, I used other sources, including the Factiva news database, OHCHR's Nepal Conflict Archive, INSEC's Human Rights Yearbooks, and Maoist writings. ${ }^{45}$

The first dependent variable, rebel violence, captures incidents of intentional, direct lethal violence against civilians. ${ }^{46}$ To test the last two hypotheses, I look at whether the civilian victim was accused of spying or informing. INSEC systematically collected such information about victims, and Joshi and Pyakurel read through all of INSEC's event descriptions to code a dummy for whether victims were accused informants. ${ }^{47}$ I split the dependent variable into rebel violence against informants - incidents where at least one victim was accused of informing - and rebel violence against non-informants - incidents where none of the victims were accused of informing.

The main explanatory variable, government attacks, captures combat events initiated by government forces. An event is coded as combat if it (a) is categorized as "combat fighting" by INSEC and/or (b) involves the death of one or more combatants. Government combatants are readily identified, but distinguishing rebels from civilians is more complicated. The victim data describes whether the victim was affiliated with the Maoist party. However, since this category may include civilian supporters, I code Maoist-affiliated persons as rebel combatants only if they (a) are killed in "combat fighting" and/or (b) have "politics" as their occupation. ${ }^{48}$ The initiator of combat events is coded as follows: For events involving crossfire, the attacker is coded as initiator. ${ }^{49}$ When the attacker cannot be ascertained, the event is coded as a clash. For events involving explosives, the actor suspected of planting or launching the device is coded as the initiator. For other attacks on combatants, such as extrajudicial killings, the perpetrating actor is coded as initiator. 


\section{Mediators, Moderators, and Controls}

According to the predation and substitution accounts, the effect of combat on rebel violence should be mediated by its outcome. I use three outcome indicators to test this claim: The first, rebel combatant losses, measures rebel fatalities as a proportion of their current force, reflecting predation theory's emphasis on absolute losses and the need for new recruits. The next two indicators capture combat performance more broadly, as emphasized in the substitution account: Rebel battle losses counts the number of events in which the rebels (a) suffered at least three fatalities more than the government did, and/or (b) failed in an attempt to overrun a government fixed position, and/or (c) lost a position to the government. ${ }^{50}$ Correspondingly, rebel battle victories includes events where the rebels (a) suffered at least three fatalities fewer than the government did, and/or (b) overran a government position, and/or (c) successfully defended a position against government attack. ${ }^{51}$

I also include several variables that may confound or moderate the effect of government attacks on rebel violence. First, rebel attacks and clashes are included since they might influence government attacks as well as rebel violence.

Local control is also likely to affect both combat and violence. Since data on local military presence is lacking, I combine two alternative indicators. The first is successful rebel attacks on security force bases, which indicate shifts in control because they often made the security forces withdraw from the lost base as well as from nearby positions. ${ }^{52}$ A base attack is coded as successful if a manned base is overrun, destroyed or plundered. I code this indicator for every base attack in the new conflict event dataset, and add events described in other sources, including INSEC's Human Rights Yearbooks and Maoist documents. ${ }^{53}$

The second indicator is the presence of a Maoist district people's government. A people's government does not mark complete rebel control, as the government controlled every district headquarters throughout the conflict. Nonetheless, it indicates considerable 
rebel influence, since the Maoists only declared a district people's government after establishing many local people's governments in a district. ${ }^{54}$ In some districts, the Maoists also aborted attempts to install a people's government because of a strong security force presence. ${ }^{55}$ To code district people's governments, I systematically search the Factiva news database and add information from other sources. ${ }^{56}$

I combine the two indicators to capture three zones of control: ${ }^{57}$ Government control is coded if the rebels up to the current week have neither overrun any security force base in the district nor set up a district people's government; contested is coded if the rebels have either overrun at least one security force base or set up a district people's government; and rebel control is coded if the rebels have both overrun at least one security force base and set up a district people's government. ${ }^{58}$ Among the 74 conflict-affected districts, 10 are coded as controlled by the government throughout the conflict, 64 become contested at some point, and 35 of these become controlled by the rebels.

Government constraints may also affect counterinsurgent tactics as well as rebel violence. ${ }^{59}$ To capture this concept, I use Polity's measure of institutional constraints on the chief executive. ${ }^{60}$ This measure changes only once during the conflict: In October 2002, when the king dismissed the parliamentary government, it goes from "substantial constraints" (6) to "unlimited executive authority" (1). I therefore employ a dummy marking the period of high constraints.

To assess whether government attacks matter less for rebel violence in urban than in rural settings, I use the proportion of the district population living in urban areas (Urban, $\%{ }^{61}$

Several national-level dynamics could also confound the results. Ceasefires are likely to restrain both combat and violence. Furthermore, I include a dummy marking the period of Maoist alliance with seven parliamentary parties (Rebel-SPA alliance), which involved a 
commitment by the Maoists not to attack civilians. I code the beginning of the alliance on June 19, 2005, when the Maoists declared they would not harm unarmed persons. ${ }^{62}$ I also control for the number of armed forces on each side, which could influence both combat and civilian killings. ${ }^{63}$ For government troops, I use estimates from The Military Balance, ${ }^{64}$ while for rebel troops, I take the average of The Military Balance estimates and government estimates. ${ }^{65}$ To account for the gradual spread of the rebels across Nepal, I divide the rebel force by the number of districts seeing at least one conflict-related fatality up to $t .{ }^{66}$ Since the government force was present in all districts from the beginning, I divide it by the total number of districts throughout the conflict. Summary statistics for all variables are found in Table A1 in the Online Appendix.

\section{Quantitative Evidence}

How do the patterns of combat and violence fit with the informational argument? First, the argument posits that informing is of greater concern to the rebels than to the government, since the rebels' survival depends on hiding. Accused informers should therefore make up a substantial proportion of victims of rebel violence, and a smaller proportion of government violence. Consistent with this implication, accused informants constitute more than one third of victims of rebel violence, but only two percent of victims of government violence (Figure $1) .^{67}$

\section{[Insert Figure 1]}

The argument also suggests that the rebels, due to their military inferiority, should hide in small groups and avoid defensive battles. Only if they choose the time and place of battle 
should the rebels stand a good chance of winning. Government attacks should therefore tend to overwhelmingly harm the rebels. The evidence supports also this implication (Figure 2): Government attacks typically produced fatalities only on the rebel side, clashes produced a more moderate fatality imbalance in the government's favor, whereas rebel attacks led to somewhat higher government than rebel fatalities.

\section{[Insert Figure 2]}

\section{Regression Analysis}

To test the hypotheses, I aggregate the variables to the district-week. The district is a suitable spatial unit because it was central to the rebels' organization as well as to the government's counterinsurgency effort. ${ }^{68}$ Importantly, this meant that suspected rebels were often arrested in one village, but killed elsewhere in the same district. ${ }^{69}$ While the most appropriate temporal unit is less clear, the week captures a plausible time lag from a government attack to a violent rebel response. To ensure that the insurgency is present in all included district-weeks, each district enters the dataset at the time of its first conflict-related fatal event.

I use an unconditional fixed-effects negative binomial model with panel-corrected standard errors. This model handles two important challenges: time-invariant confounders, which are difficult to guard against with control variables, and overdispersion in the dependent variable. ${ }^{70}$ While the incidental parameters problem is a potential concern, it is not likely to be serious here since the time series are very long. ${ }^{71}$

The results, shown in Table 1, provide much support for the argument. In the first model, I assess whether government attacks on the rebels are generally associated with more rebel violence against civilians (H1). The hypothesis is clearly supported: The government 
attacks coefficient (shown as an incidence-rate ratio) is highly significant and suggests that one more attack on the rebels is related to, on average, 25 percent more rebel violence.

\section{[Insert Table 1]}

Rebel attacks are also positively related to rebel violence. Various mechanisms might underlie this relationship: Government attacks could trigger rebel retaliation in the form of civilian killings as well as military attacks, and rebel military attacks and violence could tend to correlate because they stem from the same tactical plan or depend on the same local rebel capabilities. ${ }^{72}$ Clashes, in contrast, are not positively associated with rebel violence. Since clashes often result in rebel losses, this provides a first indication that losses per se are not a major driver of rebel violence.

The next two models further examine whether rebel losses may account for the effect of government attacks. I include rebel combatant losses in Model 2, and the two broader combat outcome indicators, rebel battles losses and rebel battle victories, in Model 3. Overall, the results do not suggest that the effect of government attacks is mediated by losses: Its estimate is not substantially weakened in any of the models, and it even slightly increases in the third model. There is also no clear indication that combat losses yield more rebel violence: None of the three estimates reach statistical significance, and the estimate for rebel battles losses has the wrong sign. ${ }^{73}$

May civilian informing instead help explain the connection between government attacks and rebel violence? To assess this, I disaggregate the dependent variable, rebel violence, by the type of victim: Model 4 looks at violence against non-informants, while Model 5 looks at violence against accused informants. In line with the informational argument, government attacks is nearly five times more strongly associated with violence 
against informants than with violence against non-informants. To assess whether the coefficients are statistically different, I combine the estimates through seemingly unrelated estimation (SUR). ${ }^{74}$ A Wald test clearly rejects similarity $(\mathrm{p}=0.003)$, in support of $H 2$.

In the last model, I assess whether the effect of government attacks on rebel violence against informers may depend on local control and urban population. To do this, I add interaction terms between government attacks and each of these variables. The percentage urban interaction is below 1, indicating that government attacks matter less for rebel violence in urban areas, as expected. The interactions involving government control and rebel control are, unexpectedly, above 1, indicating that government attacks has a larger effect in these contexts than in contested areas. While none of the interaction coefficients are significant, this does not necessarily rule out important contingencies. ${ }^{75} \mathrm{I}$ therefore graph the average predictive margins for government attacks for different levels of control and urban population in Figure $3 .^{76}$

\section{[Insert Figure 3]}

The left plot weakly indicates that control has a moderating effect. According to the mean estimates, government attacks has the strongest effect in government-controlled areas, where predicted violence increases two-and-a-half times when moving from zero to two government attacks. The estimated effect is only slightly weaker in rebel-controlled areas, whereas in contested areas, the same change gives only a 60 percent increase in predicted violence. These estimates are uncertain, however: in none of the zones are the changes in predictions from increasing government attacks significant at the 5 percent level.

The right plot gives some indication that urban population also moderates the effect of government attacks. In completely rural districts, going from zero to two government attacks 
more than doubles the predicted rebel violence, whereas it has less than half this effect where 50 percent of the population is urban. The estimates are highly uncertain for the more urban districts, however, partly because there are few such districts in Nepal. Nonetheless, the pattern is consistent with the proposition that urban terrains make it more difficult for rebels to identify civilian informers.

\section{Robustness Tests}

The main findings are robust to various modeling choices. Figure 4 plots the government attacks coefficient from various modifications of Model $1 .^{77}$ The first two rows tests alternative estimators: a fixed-effects Poisson model (Model 7), and an unconditional fixedeffects zero-inflated negative binomial model (Model 8). The latter assumes that some observations have zero chance of violence, which could be true if the rebels were cleared from a district. To model this possibility, I use a dummy marking whether there were any conflict-related fatal events in the district during the preceding six months. Model 9 includes an additional control variable: government violence against civilians ( $t$-1). Model 10 includes dummies for each year of the conflict to capture possible remaining time trends, and Model 11 addresses concerns about temporal dependence by adding a lagged dependent variable. The government attacks estimate remains stable throughout these models.

\section{[Insert Figure 4]}

Past rebel violence could conceivably both induce government attacks and render future rebel violence more likely. To examine this, I run a regression only on observations seeing no rebel violence in the preceding four weeks (Model 12). While one cannot preclude that past rebel violence plays a role also in this subsample, it is less plausible than for the rest of the sample. 
If past violence were positively confounding the government attacks estimate, it should therefore be reduced in this subsample. Instead, the government attacks estimate slightly increases, alleviating concerns about reverse causality.

The time from a government attack to a violent rebel response may often amount to more than a week, as delays can occur in the rebels' decision-making and implementation process. In Models 13-16 I therefore test four alternative lags of government attacks and the other event variables, rebel attacks and clashes. The coefficient becomes slightly stronger using a three-week lag and somewhat weaker using a five-week lag, but is significantly positive for all lags. Hence, the main inference does not depend on the lag structure.

Lastly, since conflict processes may cross district borders, I run a model including a spatially lagged dependent variable, measured as the sum of rebel violence against civilians in contiguous districts in $t-1$ (Model 17). Also here, government attacks remains significantly related to increased rebel violence.

\section{Qualitative Evidence}

To further probe the argument's plausibility, I trace the causal processes using qualitative data. The vast number of relevant observations does not allow me to give a detailed account of how government attacks led to rebel violence. Rather, the aim is to use causal-process observations to assess three central implications of the argument: First, civilian informants should be important for the government's efforts to find and attack the rebels. Second, in rural areas, the rebels should often be able to identify informers, even where they lack control. Third, the rebels should punish suspected civilian informants mainly out of security concerns.

I focus mainly on Rolpa in the mid-western hills. This district offers good opportunities for analyzing the relevant causal processes. First, it was among the districts 
most afflicted by rebel violence. In total, there were 50 rebel killings, half of which targeted accused informants. Second, as part of the region where the insurgency began, the district saw great variation in rebel control across time, making it possible to assess the second implication. Finally, several previous studies provide relevant information from this district, which allows me to triangulate data sources and make more reliable inferences.

The main data source is in-depth interviews with several former Maoist rebels, security force officers, and local civilians. ${ }^{78}$ I complement the interviews with Maoist party documents, reports, news articles, and previous studies.

\section{The Role of Informants}

In the initial years, the Maoists operated in small units, usually squads or platoons, armed only with knives, homemade explosives, and a few bolt-action rifles (Ogura, 2008: 14). They therefore hid from the police, often among the villagers. To find or identify the rebels, the police relied heavily on local informants. Many of these informants were local strongmen affiliated with the established political parties, who collaborated closely with the police. ${ }^{79}$ In Jelbang village of Rolpa, for instance, the police resided in the house of a Nepali Congress supporter. $^{80}$

Informants aided the police in various ways: They revealed the identity of Maoists, led the way to rebel hideouts, and sometimes joined the police when searching the villages. Such collaborative searches were effective, according to a Maoist from Rolpa, since most villagers would reveal nothing if the police came alone, but were compelled to speak if more knowledgeable local informants came along. ${ }^{81}$

After a few years, many villages were emptied of voluntary informants, however. Especially from 1999 onward, the Maoists grew stronger, and successful raids on police stations made the police abandon more and more posts in Rolpa. ${ }^{82}$ Lacking protection in the 
villages, government administrators and people opposed to the Maoists began moving to the government-controlled district headquarters, Liwang, or further away. ${ }^{83}$ Others stayed on in the villages, but stopped talking to the police, as the Maoists could credibly threaten them with punishment. $^{84}$

Information from civilians remained important for finding the rebels, however. Although the Maoists strengthened their People's Liberation Army and ruled villages through people's governments, they still evaded the security forces and did not defend fixed positions. Even when security forces moved into the Maoists' headquarters in northern Rolpa in 2005, the rebels fled in advance. "There was no Maoist base to attack," recounted a former Royal Nepal Army officer.

The security forces therefore kept relying on civilian informants. Many civilians who fled to the district headquarters continued collaborating with the police, providing information and joining them in searches. ${ }^{86}$ The security forces would also take in Maoist supporters during patrols and pressure them into leading the way to Maoist hideouts. ${ }^{87}$ Throughout the war, then, the government used informants to find and attack the rebels.

\section{Rebel Identification of Informants}

The Maoists were usually well informed about civilian collaboration with the government, also where they lacked local control. Consistent with this, killings of government informants occurred quite frequently also in areas of government control. In Jelbang village of Rolpa, for instance, the rebels killed four accused informants during the initial years, although the police

had two local posts in the village. ${ }^{88}$ Even in the district headquarters, informants were not completely safe, as the rebels killed three informants there in the latter half of the war. ${ }^{89}$

The Maoists were apt at identifying informers in Rolpa partly because of their strong local political foothold and social ties. Many villagers sided with the Maoists and had friends 
or family members in the rebel force, and therefore felt obliged to help them. ${ }^{90}$ Also importantly, the Maoists became adept at forming local monitoring institutions. In each village, they first created civilian front organizations and later a people's government. Furthermore, they formed local village militias of youngsters, whose main task was to report about informants and the security forces. Through such organizations, the rebels often monitored the villages closely also before gaining local control. ${ }^{91}$

Maoist monitoring was often effective also in areas where they lacked broad popular support. After clearing the security forces from an area, they would set up local institutions and, if necessary, compel villagers to join them. While this practice sometimes made civilians confront the Maoists, more often, it seems, people either complied or fled to governmentcontrolled areas. $^{92}$ In Barchhen of Doti district, for instance, where the Maoists were relatively late to arrive, most villagers, even those supporting other parties, became involved in local Maoist organizations. ${ }^{93}$

Once such institutions were made, they gave the Maoists influence and information disproportionate to their military power. To function, the institutions did not require a permanently stationed Maoist force, only the knowledge that the Maoists could arrive to punish wrongdoers at any time. $^{94}$

\section{Rebel Motivations for Violence}

Why did the rebels kill accused informants after being attacked by government forces? The main motivation, it appears, was to deter informing and thereby avoid being captured or killed. These were certainly important concerns for the Maoist leadership, who openly encouraged the execution of informants. In 1997, for instance, the party launched a campaign named "Make the Elephant Blind," whose purpose was to paralyze the state forces by removing their local civilian agents - their eyes in the village. ${ }^{95}$ Also tellingly, in a Maoist 
publication from the same year, targeted civilians were systematically described as babblers (phataha) and informants (suraki). ${ }^{96}$

The Maoists also had other reasons for killing civilians, such as to make people follow their rules and to weaken local political opposition. ${ }^{97}$ The latter motive can be difficult to distinguish from deterrence, however, since the most active informants often also belonged to other political parties. Expectedly, many accused informants killed by Maoists were also cadres from other political parties. However, rebel punishment was by no means limited to such cadres: According to INSEC's data, 36 percent of victims accused of informing were affiliated with another political party. Furthermore, the rebels did not specifically target people of higher caste. Victims of Maoist violence were of various ethnic and caste backgrounds, and included non-caste Janajatis (30 percent) and low-caste Dalits (7 percent). ${ }^{98}$

The Maoists emphasize that they killed people not because of their political affiliation or class, but because they had collaborated with the government. When asked why supporters of other parties were killed, a former Maoist brigade commander answered:

They were informants of the police, so they were punished because they were going against the People's War. One example is from Kalagaun, where one person had shown the security forces a Maoist shelter, which led to the killing of three Maoists. We warned him not to inform on us, but he did not follow our warning. So we killed him. ${ }^{99}$

Maoist ex-combatants from Rolpa also emphasized that punishment was contingent on people's behavior. According to one, "[w]e used to do executions (saphaya) only as the last resort, if they inform on us for the third time despite our suggestion not to inform on us." 
Another local leader explained that "[w]e did saphaya of two people. What they had done was directly bringing police into the village and killing our people."

In line with these statements, not everyone reporting on the Maoists was killed. In Jankot of Rolpa, once the police withdrew, the Maoists kidnapped two notorious informants affiliated with Nepali Congress. After promising not to collaborate with the security forces, they were both released and stayed undisturbed in the village. ${ }^{101}$

The rebels, this suggests, often used violence strategically: When revenge was not expected to further the party's longer-term aims, they abstained from it. ${ }^{102}$ Not all rebel violence was strategic, however. Nonstrategic use of violence appears to have increased in the later years, not the least because rapid expansion led to less screening and training of new recruits. ${ }^{103}$ In 2003, the Maoist Politburo also admitted that there had been deviations from the party line, including killings for reasons such as political opposition or bad blood. However, they stressed the importance of adhering to "a certain minimum legal method," and that punishment "should be not because of his/her membership of a particular political party but due to his/her crime against the people and the People's War."104

While these statements resonate with theories emphasizing principal-agent problems and nonstrategic purposes of violence, ${ }^{105}$ they also underscore that the Maoist leadership acted to prevent opportunistic behavior. To achieve this, they had a political commissar lead fighting units alongside a military commander. This command structure remained intact throughout the war, and probably helped avoid a descent into rampant opportunism and abuse. Despite the increasing difficulty of maintaining discipline, Maoist violence against civilians actually declined nationwide since $2004,{ }^{106}$ suggesting that the Maoist leadership still exerted considerable control over its forces. 


\section{Conclusion}

This article has scrutinized how combat relates to rebel violence against civilians. Existing studies have suggested that combat affects rebel violence indirectly, by producing rebel losses or shifting local patterns of control. I have proposed a different link stemming from the logic of insurgency warfare: Since the insurgents are hiding, government forces tend to rely on civilian informants to find and attack them. Consequently, government attacks often leave informants exposed, and trigger punitive rebel violence to prevent future information leaks.

This argument found much support in a mixed-methods analysis of the Maoist insurgency in Nepal. The quantitative analysis showed that government attacks were positively related to rebel violence, even when controlling for the size of rebel losses and local control. Furthermore, consistent with the informational mechanism, government attacks were strongly related to rebel violence against suspected informants, but not to violence against other civilians.

The process-tracing analysis provided further evidence about the mechanisms involved. Consistent with the argument, the Nepalese Maoists were mostly hiding, and the government often relied on civilian informants to find them, also in areas controlled by the rebels. With the aid of local clandestine institutions and supporters, the rebels were often able to identify and subsequently threaten or punish the government informants. Also as expected, the Maoists defended such punishment as strategic acts to prevent information leaks.

Not all Maoist violence was strategic, however. Many civilians were killed without being accused of informing, and such killings were not predicted by government attacks. The Maoist leadership also acknowledged problems of opportunistic violence in later stages of the war. Plausibly, such violence may be better explained by organizational and ideational factors than by strategic interaction between rebels and the government. 
Also importantly, the role of informing for rebel violence might vary across contexts. I found some indication that local control moderates the association between government attacks and rebel violence, although the association was positive for all control zones. This contingency should be further explored for other conflicts, preferably with more detailed measures of control. Furthermore, the data indicated that the link between government attacks and rebel violence is weaker in urban areas, where identifying informants is more difficult. The argument might also be less applicable to conflicts involving a highly capable state, which can rely on direct surveillance or rebel defectors to find the rebels. Finally, the argument should not apply to conventional wars, where the rebels defend fixed positions.

In spite of these possible contingencies, the argument probably extends far beyond the Nepalese conflict. Many of this conflict's characteristics, such as guerrilla warfare and a rural focus, are commonly found in civil wars. We also know that many insurgent groups employ violence to prevent information leaks. In the imagery of the Nepalese Maoists, by cleansing the villages of informants, they hope to render their more powerful opponent a "blind elephant," stomping aimlessly around. Government attacks provide an impetus to such cleansing because they often carry information about civilian betrayal.

More broadly, the study suggests that much rebel violence is strategic and closely connected to guerrilla warfare. This fits well with the control-collaboration theory of violence, which similarly emphasizes the role of information for wartime violence. There are points of difference, however. Most notably, the study challenges the notion that the rebels and the government usually kill for the same reasons: Since the weaker rebels are hiding, they become more concerned than the government with deterring denunciations. In other words, the asymmetry in power produces asymmetry not only in military tactics, but also in violence against civilians. 
Table 1. Negative Binomial Models of Rebel Violence

\begin{tabular}{|c|c|c|c|c|c|c|}
\hline & \multicolumn{3}{|c|}{ DV: Rebel violence (all) } & \multirow{2}{*}{$\begin{array}{c}\text { DV: Rebel } \\
\text { violence } \\
\text { against non- } \\
\text { informants } \\
\text { Model } 4\end{array}$} & \multicolumn{2}{|c|}{$\begin{array}{l}\text { DV: Rebel violence against } \\
\text { informants }\end{array}$} \\
\hline & Model 1 & Model 2 & Model 3 & & Model 5 & Model 6 \\
\hline $\begin{array}{l}\text { Government } \\
\text { attacks, t-1 }\end{array}$ & $\begin{array}{l}1.242^{\pi \pi \pi} \\
(0.0718)\end{array}$ & $\begin{array}{l}1.232^{\pi \pi} \\
(0.0809)\end{array}$ & $\begin{array}{l}1.257^{\pi \times \pi} \\
(0.0764)\end{array}$ & $\begin{array}{c}1.091 \\
(0.0688)\end{array}$ & $\begin{array}{l}1.442^{\pi \pi \pi} \\
(0.113)\end{array}$ & $\begin{array}{l}1.288^{\pi} \\
(0.152)\end{array}$ \\
\hline Rebel attacks, t-1 & $\begin{array}{l}1.273^{\star \pi} \\
(0.112)\end{array}$ & $\begin{array}{l}1.267^{\star \pi} \\
(0.115)\end{array}$ & $\begin{array}{l}1.347^{\pi \pi \pi} \\
(0.122)\end{array}$ & $\begin{array}{c}1.180 \\
(0.119)\end{array}$ & $\begin{array}{l}1.415^{\pi \pi} \\
(0.155)\end{array}$ & $\begin{array}{l}1.411^{\pi \pi} \\
(0.152)\end{array}$ \\
\hline Clashes, t-1 & $\begin{array}{c}0.990 \\
(0.0961)\end{array}$ & $\begin{array}{c}0.982 \\
(0.0931)\end{array}$ & $\begin{array}{c}1.015 \\
(0.101)\end{array}$ & $\begin{array}{c}1.133 \\
(0.130)\end{array}$ & $\begin{array}{l}0.728 \\
(0.124)\end{array}$ & $\begin{array}{l}0.719^{*} \\
(0.113)\end{array}$ \\
\hline $\begin{array}{l}\text { Rebel combatant } \\
\text { losses, } t-1\end{array}$ & & $\begin{array}{c}1.403 \\
(1.096)\end{array}$ & & & & \\
\hline $\begin{array}{l}\text { Rebel battle } \\
\text { losses, } t-1\end{array}$ & & & $\begin{array}{c}0.780 \\
(0.182)\end{array}$ & & & \\
\hline $\begin{array}{l}\text { Rebel battle } \\
\text { victories, } t-1\end{array}$ & & & $\begin{array}{c}0.605 \\
(0.182)\end{array}$ & & & \\
\hline $\begin{array}{l}\text { Government } \\
\text { control }\end{array}$ & $\begin{array}{c}0.925 \\
(0.145)\end{array}$ & $\begin{array}{c}0.925 \\
(0.145)\end{array}$ & $\begin{array}{c}0.922 \\
(0.144)\end{array}$ & $\begin{array}{c}1.034 \\
(0.185)\end{array}$ & $\begin{array}{c}0.758 \\
(0.149)\end{array}$ & $\begin{array}{c}0.728 \\
(0.144)\end{array}$ \\
\hline Rebel control & $\begin{array}{l}0.533^{\pi \pi} \\
(0.109)\end{array}$ & $\begin{array}{l}0.534^{\pi \pi} \\
(0.109)\end{array}$ & $\begin{array}{l}0.533^{\pi \pi} \\
(0.109)\end{array}$ & $\begin{array}{l}0.582^{\pi} \\
(0.132)\end{array}$ & $\begin{array}{l}0.444^{\pi \pi} \\
(0.111)\end{array}$ & $\begin{array}{l}0.406^{\pi \pi} \\
(0.113)\end{array}$ \\
\hline $\begin{array}{l}\text { Gov. attacks * } \\
\text { Gov. control }\end{array}$ & & & & & & $\begin{array}{c}1.215 \\
(0.192)\end{array}$ \\
\hline $\begin{array}{l}\text { Gov. attacks * } \\
\text { Rebel control }\end{array}$ & & & & & & $\begin{array}{c}1.245 \\
(0.208)\end{array}$ \\
\hline $\begin{array}{l}\text { Gov. attacks * } \\
\text { Urban (\%) }\end{array}$ & & & & & & $\begin{array}{c}0.996 \\
(0.00742)\end{array}$ \\
\hline Ceasefire & $\begin{array}{l}0.312^{\star \star \star} \\
(0.0357)\end{array}$ & $\begin{array}{l}0.312^{\star \star \star} \\
(0.0357)\end{array}$ & $\begin{array}{l}0.312^{\star \star \star} \\
(0.0357)\end{array}$ & $\begin{array}{l}0.360^{\star \star \star} \\
(0.0513)\end{array}$ & $\begin{array}{l}0.218^{\star \star \star} \\
(0.0492)\end{array}$ & $\begin{array}{l}0.217^{\star \star \star} \\
(0.0492)\end{array}$ \\
\hline $\begin{array}{c}\text { Rebel-SPA } \\
\text { alliance }\end{array}$ & $\begin{array}{l}0.628^{\times} \\
(0.147)\end{array}$ & $\begin{array}{l}0.627^{\pi} \\
(0.147)\end{array}$ & $\begin{array}{l}0.632^{\pi} \\
(0.148)\end{array}$ & $\begin{array}{c}0.621 \\
(0.168)\end{array}$ & $\begin{array}{c}0.559 \\
(0.189)\end{array}$ & $\begin{array}{c}0.557 \\
(0.189)\end{array}$ \\
\hline $\begin{array}{l}\text { Government } \\
\text { constraints }\end{array}$ & $\begin{array}{l}1.391^{*} \\
(0.179)\end{array}$ & $\begin{array}{c}1.390^{*} \\
(0.179)\end{array}$ & $\begin{array}{l}1.397^{* \star} \\
(0.179)\end{array}$ & $\begin{array}{l}1.534^{\star \star} \\
(0.235)\end{array}$ & $\begin{array}{c}1.125 \\
(0.218)\end{array}$ & $\begin{array}{c}1.132 \\
(0.216)\end{array}$ \\
\hline Rebel troops & $\begin{array}{l}0.172^{\pi \pi \pi} \\
(0.0806)\end{array}$ & $\begin{array}{l}0.173^{\pi \pi \pi} \\
(0.0807)\end{array}$ & $\begin{array}{l}0.173^{\pi \pi \pi} \\
(0.0806)\end{array}$ & $\begin{array}{c}0.300^{\pi} \\
(0.160)\end{array}$ & $\begin{array}{l}0.0474^{\pi \pi \pi} \\
(0.0304)\end{array}$ & $\begin{array}{l}0.0476^{\pi \pi \pi} \\
(0.0306)\end{array}$ \\
\hline $\begin{array}{l}\text { Government } \\
\text { troops }\end{array}$ & $\begin{array}{c}1.260^{\star \star \star} \\
(0.0292)\end{array}$ & $\begin{array}{l}1.260^{\star \star \star} \\
(0.0293)\end{array}$ & $\begin{array}{l}1.260^{* * *} \\
(0.0292)\end{array}$ & $\begin{array}{c}1.269^{\star \star \star} \\
(0.0339)\end{array}$ & $\begin{array}{l}1.258^{\star \star \star} \\
(0.0370)\end{array}$ & $\begin{array}{l}1.261^{\star \star *} \\
(0.0376)\end{array}$ \\
\hline $\begin{array}{l}\text { District fixed } \\
\text { effects? }\end{array}$ & Yes & Yes & Yes & Yes & Yes & Yes \\
\hline $\begin{array}{l}\text { Districts } \\
\text { Observations }\end{array}$ & $\begin{array}{c}74 \\
27659\end{array}$ & $\begin{array}{c}74 \\
27659 \\
\end{array}$ & $\begin{array}{c}74 \\
27659 \\
\end{array}$ & $\begin{array}{c}74 \\
27659 \\
\end{array}$ & $\begin{array}{c}74 \\
27659 \\
\end{array}$ & $\begin{array}{c}74 \\
27659 \\
\end{array}$ \\
\hline
\end{tabular}

Exponentiated coefficients. Clustered standard errors in parentheses $* \mathrm{p}<0.05, * * \mathrm{p}<0.01, * * * \mathrm{p}<0.001$.

District dummies and the constant not shown. 


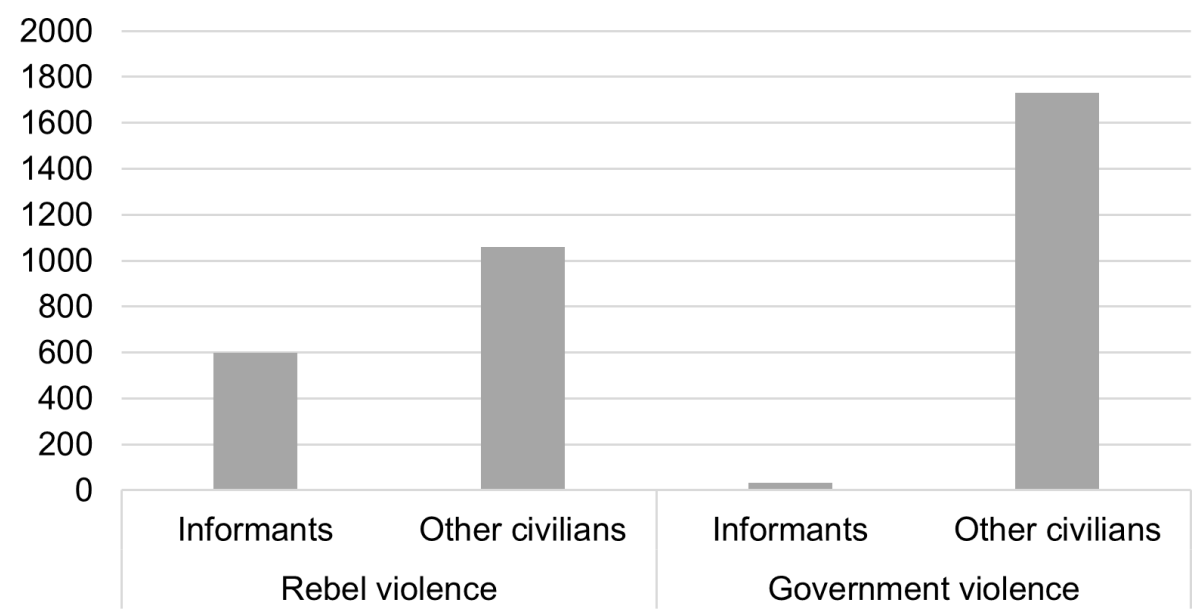

Figure 1. Rebel and Government Violence against Civilians

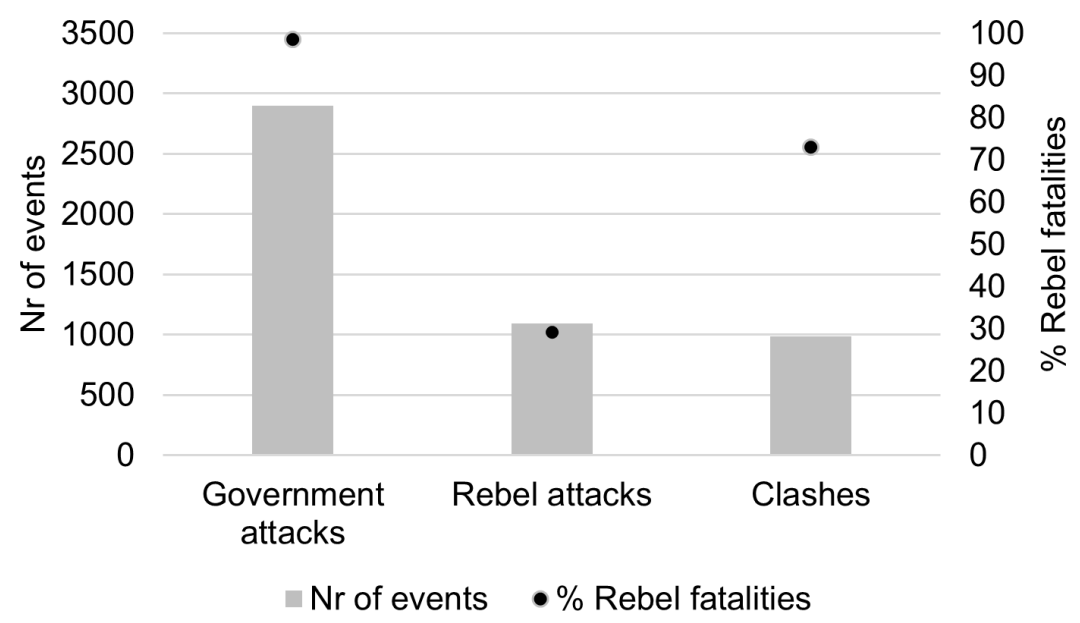

Figure 2. Combat Events and Outcomes 

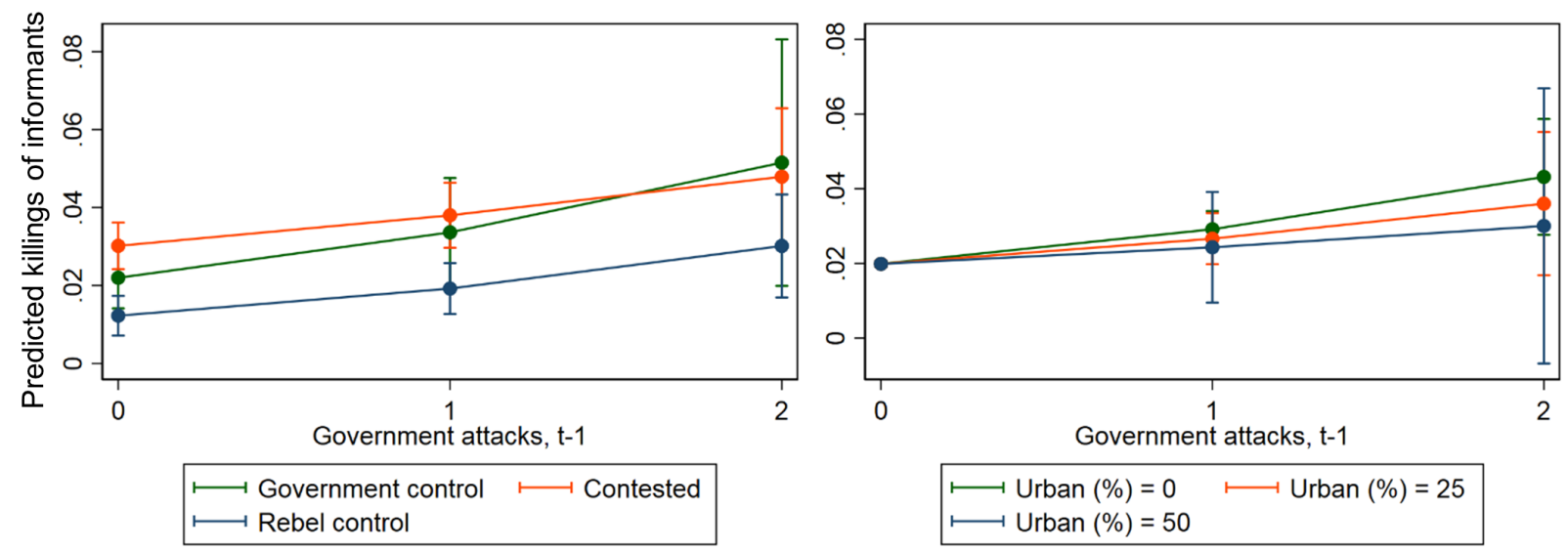

Figure 3. Average Predictive Margins for Government Attacks Conditional on Other Variables

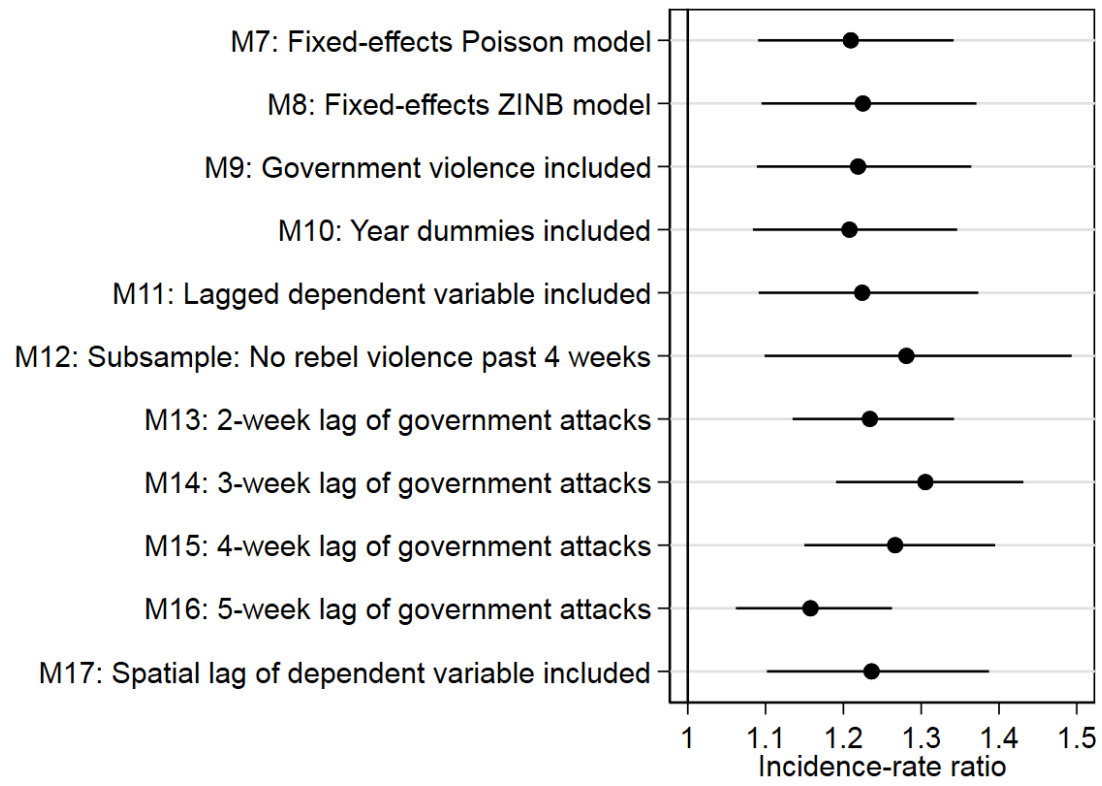

Figure 4. Robustness Tests: Governmant Attacks Coefficients with 95\% Confidence Intervals Note: The dependent variable is rebel violence. Each row represents a separate model. Coefficients for other variables are omitted from the figure. 


\section{Notes}

${ }^{1}$ Based on data from Luis De la Calle, "Compliance vs. Constraints: A Theory of Rebel Targeting in Civil War," Journal of Peace Research 54, no. 3 (2017): 427-441.

${ }^{2}$ Ralph Sundberg and Erik Melander, "Introducing the UCDP Georeferenced Event Dataset," Journal of Peace Research 50, no. 4 (2013): 523-532.

${ }^{3}$ Madhav Joshi and Subodh Raj Pyakurel, "Individual-Level Data on the Victims of Nepal's Civil War, 19962006: A New Data Set," International Interactions 41, no. 3 (2015): 601-619.

${ }^{4}$ E.g., Hanne Fjelde and Lisa Hultman, "Weakening the Enemy A Disaggregated Study of Violence against Civilians in Africa," Journal of Conflict Resolution 58, no. 7 (October 1, 2014): 1230-57, doi:10.1177/0022002713492648; L. Heger and I. Salehyan, "Ruthless Rulers: Coalition Size and the Severity of Civil Conflict," International Studies Quarterly 51, no. 2 (2007): 385-403; S. M. Murshed and S. Gates, "Spatial-Horizontal Inequality and the Maoist Insurgency in Nepal," Review of Development Economics 9, no. 1 (2005): 121-34; Mani Nepal, Alok K. Bohara, and Kishore Gawande, "More Inequality, More Killings: The Maoist Insurgency in Nepal," American Journal of Political Science 55, no. 4 (2011): 886-906; Sebastian Schutte, "Geographic Determinants of Indiscriminate Violence in Civil Wars," Conflict Management and Peace Science 34, no. 4 (July 1, 2017): 380-405, doi:10.1177/0738894215593690; Jessica A. Stanton, "Terrorism in the Context of Civil War," The Journal of Politics 75, no. 04 (2013): 1009-1022; Jeremy M. Weinstein, Inside Rebellion: The Politics of Insurgent Violence (New York: Cambridge University Press, 2007).

${ }^{5}$ Stathis N. Kalyvas, The Logic of Violence in Civil War (New York: Cambridge University Press, 2006).

${ }^{6}$ Lisa Hultman, "Battle Losses and Rebel Violence: Raising the Costs for Fighting," Terrorism and Political Violence 19, no. 2 (2007): 205; Lisa Hultman, "Military Offensives in Afghanistan: A Double-Edged Sword," International Area Studies Review 15, no. 3 (2012): 230-248.

${ }^{7}$ Max Abrahms and Philip BK Potter, "Explaining Terrorism: Leadership Deficits and Militant Group Tactics," International Organization 69, no. 02 (2015): 311-342; Reed M. Wood, "From Loss to Looting? Battlefield Costs and Rebel Incentives for Violence," International Organization 68, no. 04 (September 2014): 979-999. ${ }^{8}$ A similar distinction is made by Harrison R. Wagner, "Bargaining and War," American Journal of Political Science, 2000, 473.

9 Jason Lyall, "Does Indiscriminate Violence Incite Insurgent Attacks? Evidence from Chechnya," Journal of Conflict Resolution 53, no. 3 (2009): 331-362.

${ }^{10}$ Wood, "From Loss to Looting?"

${ }^{11}$ Hultman, "Battle Losses and Rebel Violence"; Hultman, "Military Offensives in Afghanistan"; Wood, "From Loss to Looting?" Existing research is more divided about how combat and losses affect rebel armed activity more generally. See e.g., Laura Dugan and Erica Chenoweth, "Moving Beyond Deterrence: The Effectiveness of Raising the Expected Utility of Abstaining from Terrorism in Israel," American Sociological Review 77, no. 4 (August 1, 2012): 597-624, doi:10.1177/0003122412450573; "Beheading the Hydra: Counterinsurgent Violence and Insurgent Attacks in Iraq," Terrorism and Political Violence 30, no. 3 (2018): 384-407; Lyall, "Does Indiscriminate Violence Incite Insurgent Attacks?"; Monica Duffy Toft and Yuri M. Zhukov, "Denial and Punishment in the North Caucasus Evaluating the Effectiveness of Coercive Counter-Insurgency," Journal of Peace Research 49, no. 6 (November 1, 2012): 785-800, doi:10.1177/0022343312448389.

12 Wood, "From Loss to Looting?"

${ }^{13}$ Hultman, "Battle Losses and Rebel Violence"; Hultman, "Military Offensives in Afghanistan."

${ }^{14}$ Ethan Bueno De Mesquita, "Rebel Tactics," Journal of Political Economy 121, no. 2 (2013): 323-357.

${ }^{15}$ Max Abrahms, "Why Terrorism Does Not Work," International Security 31, no. 2 (2006): 42-78; Daniel S. Blocq, "The Grassroots Nature of Counterinsurgent Tribal Militia Formation: The Case of the Fertit in Southern Sudan, 1985-1989," Journal of Eastern African Studies 8, no. 4 (2014): 710-724.

${ }^{16}$ Idean Salehyan, David Siroky, and Reed M. Wood, "External Rebel Sponsorship and Civilian Abuse: A Principal-Agent Analysis of Wartime Atrocities," International Organization 68, no. 03 (2014): 633-661; Reed M. Wood, "Opportunities to Kill or Incentives for Restraint? Rebel Capabilities, the Origins of Support, and Civilian Victimization in Civil War," Conflict Management and Peace Science 31, no. 5 (November 1, 2014): 461-80.

${ }^{17}$ Abrahms and Potter, "Explaining Terrorism"; A related argument is made in Humphreys and Weinstein "Handling and Manhandling Civilians in Civil War," American Political Science Review 100, no. 3 (2006): 42947.

${ }^{18}$ Kalyvas, The Logic of Violence in Civil War.

${ }^{19}$ J. D. Fearon and D. D. Laitin, "Ethnicity, Insurgency, and Civil War," American Political Science Review 97, no. 1 (2003): 80; David Galula, Counterinsurgency Warfare: Theory and Practice (New York: Praeger, 1964), 10; Vo Nguyen Giap, Military Art of People's War: Selected Writings, ed. Russell Stetler (Monthly Review Press, 1970), 94. 
${ }^{20}$ E. Berman, J. N. Shapiro, and J. H. Felter, "Can Hearts and Minds Be Bought? The Economics of Counterinsurgency in Iraq," Journal of Political Economy 119, no. 4 (2011): 766-819; Nathan Leites and Charles Wolf, Rebellion and Authority; an Analytic Essay on Insurgent Conflicts, Markham Series in Public Policy Analysis (Chicago: Markham Pub. Co., 1970), 9; Jason Lyall, Yuki Shiraito, and Kosuke Imai, "Coethnic Bias and Wartime Informing," The Journal of Politics 77, no. 3 (July 1, 2015): 833-48, doi:10.1086/681590; Jacob N. Shapiro and Nils B. Weidmann, "Is the Phone Mightier than the Sword? Cellphones and Insurgent Violence in Iraq," International Organization 69, no. 2 (2015): 247-274.

${ }^{21}$ Che Guevara, Guerrilla Warfare, trans. Brian Loveman and Thomas M. Davies (SR Books, 1961), 67.

${ }^{22}$ Daniel James, Ché Guevara: A Biography (Rowman \& Littlefield, 1970), 14.

${ }^{23}$ Ibid., 115.

${ }^{24}$ Kalyvas, The Logic of Violence in Civil War, 26.

${ }^{25}$ Military Art of People's War, 88.

${ }^{26}$ Thomas Joscelyn and Bill Roggioa, "Mullah Omar Orders Taliban to Attack Civilians, Afghan Women," FDD's Long War Journal, (July 28, 2010), https://www.longwarjournal.org/archives/2010/07/mullah_omar_orders_t.php.

${ }^{27}$ Robert Taber, War of the Flea: The Classic Study of Guerrilla Warfare (London: Paladin, 1972), 106.

${ }^{28}$ Lyall, Shiraito, and Imai, "Coethnic Bias and Wartime Informing"; Roger Dale Petersen, Resistance and Rebellion : Lessons from Eastern Europe (Cambridge ; New York: Cambridge University Press, 2001); Timothy P. Wickham-Crowley, Guerrillas and Revolution in Latin America: A Comparative Study of Insurgents and Regimes since 1956 (Princeton, N.J.: Princeton University Press, 1992); Elisabeth Jean Wood, Insurgent Collective Action and Civil War in El Salvador (New York: Cambridge University Press, 2003).

${ }^{29}$ Eli Berman and David D. Laitin, "Religion, Terrorism and Public Goods: Testing the Club Model," Journal of Public Economics 92, no. 10-11 (2008): 1942-1967; Zachariah Cherian Mampilly, Rebel Rulers: Insurgent Governance and Civilian Life during War (Cornell University Press, 2012); Sarah Elizabeth Parkinson, "Organizing Rebellion: Rethinking High-Risk Mobilization and Social Networks in War," American Political Science Review 107, no. 3 (2013): 418-432.

${ }^{30}$ Consistent with this argument, available evidence suggests that rebels tend to employ more selective violence in areas outside their control than predicted from control-collaboration theory. See Luis De la Calle, "Compliance vs. Constraints: A Theory of Rebel Targeting in Civil War," Journal of Peace Research 54, no. 3 (2017): 434; Kalyvas, The Logic of Violence in Civil War, 206; S. N. Kalyvas and M. A. Kocher, "The Dynamics of Violence in Vietnam: An Analysis of the Hamlet Evaluation System (HES)," Journal of Peace Research 46, no. 3 (2009): 345; Gonzalo Vargas, "Urban Irregular Warfare and Violence against Civilians: Evidence from a Colombian City," Terrorism and Political Violence 21, no. 1 (2009): 125.

${ }^{31}$ Ravi Bhavnani, Dan Miodownik, and Hyun Jin Choi, "Three Two Tango: Territorial Control and Selective Violence in Israel, the West Bank, and Gaza," Journal of Conflict Resolution 55, no. 1 (February 1, 2011): 13358, doi:10.1177/0022002710383663; Vargas, "Urban Irregular Warfare and Violence against Civilians."

${ }^{32}$ Kalyvas, The Logic of Violence in Civil War.

${ }^{33}$ Fearon and Laitin, "Ethnicity, Insurgency, and Civil War"; Shapiro and Weidmann, "Is the Phone Mightier than the Sword?"

${ }^{34}$ Fearon and Laitin, "Ethnicity, Insurgency, and Civil War"; Helge Holtermann, "Explaining the DevelopmentCivil War Relationship,” Conflict Management and Peace Science 29, no. 1 (2012): 56-78, doi:10.1177/0738894211430279; Andreas Forø Tollefsen and Halvard Buhaug, "Insurgency and Inaccessibility," International Studies Review 17, no. 1 (March 2015): 6-25, doi:10.1111/misr.12202.

${ }^{35}$ I consider the conflict as ending with the ceasefire of April 26, 2006, which held until a comprehensive peace agreement was signed seven months later.

36 Joshi and Pyakurel, "Individual-Level Data on the Victims of Nepal's Civil War, 1996-2006."

${ }^{37}$ S. Gates and J. Miklian, "Strategic Revolutionary Phases of the Maoist Insurgency in Nepal," in Warfare and Politics in South Asia from Ancient to Modern Times, ed. K. Roy (New Delhi: Manohar, 2011); Nihar Nayak, "The Maoist Movement in Nepal and Its Tactical Digressions: A Study of Strategic Revolutionary Phases, and Future Implications," Strategic Analysis 31, no. 6 (2007): 915-942.

${ }^{38}$ Helge Holtermann, "Relative Capacity and the Spread of Rebellion: Insights from Nepal," Journal of Conflict Resolution 60, no. 3 (2016): 501-529.

${ }^{39}$ Joshi and Pyakurel, "Individual-Level Data on the Victims of Nepal's Civil War, 1996-2006."

${ }^{40}$ Several previous studies have used INSEC's data, e.g., A. K. Bohara, N. J. Mitchell, and M. Nepal,

"Opportunity, Democracy, and the Exchange of Political Violence - A Subnational Analysis of Conflict in

Nepal," J Conflict Resolut 50, no. 1 (2006): 108-28; Holtermann, "Relative Capacity and the Spread of Rebellion"; Madhav Joshi, "Livelihood Coping Mechanisms, Local Intelligence, and the Pattern of Violence During the Maoist Insurgency in Nepal," Terrorism and Political Violence 25, no. 5 (2013): 820-39, 
doi:10.1080/09546553.2012.700657; Nepal, Bohara, and Gawande, “More Inequality, More Killings.”. None of these studies distinguish between combat and violence against civilians, however.

${ }^{41}$ Pamela E. Oliver and Daniel J. Meyer, "How Events Enter the Public Sphere: Conflict, Location, and Sponsorship in Local Newspaper Coverage of Public Events," American Journal of Sociology 105, no. 1 (July 1 , 1999): 38-87, doi:10.1086/210267; Nils B. Weidmann, "A Closer Look at Reporting Bias in Conflict Event Data," American Journal of Political Science 60, no. 1 (January 1, 2016): 206-18, doi:10.1111/ajps.12196.

${ }^{42}$ Such information is lacking for the most relevant global dataset, UCDP's Georeferenced Event Dataset.

Sundberg and Melander, "Introducing the UCDP Georeferenced Event Dataset."

${ }^{43}$ The ward is the lowest administrative level in Nepal, containing on average around 650 inhabitants. Nepal Central Bureau of Statistics, National Population Census 2001 - Nepal: Study Documentation. (Kathmandu: Nepal Central Bureau of Statistics, 2011), 3, 50.

${ }^{44}$ INSEC (Informal Sector Service Center), "Conflict Victims' Profile," Online Database, (2017). A Nepalese research assistant translated this text from Nepali and performed the coding based on this source.

${ }^{45}$ CPN-Maoist, "New Experiences Gained in Capturing Sandhikharka," The Worker, January 2003; CPN-

Maoist, "Chronology of Major Political Events and Military Raids during 10 Years of People's War," The Worker, May 2006; INSEC (Informal Sector Service Center), "Human Rights Yearbooks" (Kathmandu: INSEC, 1998, 1999, 2000, 2001, 2002, 2003, 2004, 2005, 2006 1997); OHCHR, "Nepal Conflict Archive," Online Database, (2015), http://nepalconflictreport.ohchr.org; Pasang, Red Strides of the History (Kathmandu: Agnipariksha Janprakashan Griha, 2008).

${ }^{46}$ Civilian deaths from combat, disease, or starvation are excluded from the measure. Also excluded are fatalities caused by landmines and accidents, such as children tampering with explosives.

${ }^{47}$ The accuracy of the coding is difficult to probe. However, there is no clear reason to suspect systematic measurement error, since the two most plausible error sources work in opposite directions: On one hand, INSEC may not always find information about the perpetrators' motives, but on the other, perpetrators may falsely accuse victims of informing because this is seen as a legitimate reason for punishment.

${ }^{48}$ Maoists working with politics were probably combatants, since most full-timers, including in the political and cultural wings of the party, participated in armed actions (Author's interview with Maoist activist and lawyer, Kathmandu, August 2014). Three fourths of victims of government violence were affiliated with the Maoist party. Among these, 87 percent were coded as combatants.

${ }^{49}$ Retaliation immediately after an attack is coded as part of the initial event.

${ }^{50}$ Fixed positions include police stations and military bases and camps.

${ }^{51}$ The temporal domain for calculating these variables is the week.

${ }^{52}$ Thomas A. Marks, Insurgency in Nepal (Strategic Studies Institute, 2003), 15; Deepak Thapa, Kiyoko Ogura, and Judith Pettigrew, "The Social Fabric of the Jelbang Killings, Nepal," Dialectical Anthropology 33, no. 3 (2009): 461-478.

${ }^{53}$ CPN-Maoist, "Chronology of Major Political Events and Military Raids during 10 Years of People's War"; INSEC (Informal Sector Service Center), "Human Rights Yearbooks"; Pasang, Red Strides of the History.

${ }^{54}$ M. Hatlebakk, "Maoist Control and Level of Civil Conflict in Nepal," South Asia Economic Journal 11, no. 1 (2010): 99; Kiyoko Ogura, "Maoist People's Governments, 2001-05: The Power in Wartime," Local Democracy in South Asia: Microprocesses of Democratization in Nepal and Its Neighbours, 2008, 175-231.

${ }_{55}$ Agence France Presse, "Residents of Eastern Nepal Head Home after Maoists Lift Attack Threat," September 9, 2004.

${ }^{56}$ Ogura, "Maoist People's Governments, 2001-05"; Sudheer Sharma, "The Maoist Movement: An Evolutionary Perspective," in Himalayan People's War, ed. Michael Hutt (Bloomington, IN: Indiana University Press, 2004), 38-57.

${ }^{57}$ A three-zone control scale is also used for the Sendero Luminoso conflict by De la Calle, "Compliance vs. Constraints: A Theory of Rebel Targeting in Civil War."

${ }^{58}$ Notably, the measure does not capture shifts in control toward the government. Substantial reversals of rebel control appear to be rare in Nepal, however. Some army bases were installed in the second half of the conflict, but they were far apart, and typically did not fill the gaps created by earlier police withdrawal. In Rolpa, for instance, the police abandoned around 30 police posts between 1996 and 2001 . When the army entered in late 2001, it set up only a few bases, leaving most villages under rebel control. Marks, Insurgency in Nepal, 15; Pasang, Red Strides of the History, 50, 157; Thapa, Ogura, and Pettigrew, "The Social Fabric of the Jelbang Killings, Nepal."

${ }^{59}$ Daniel Byman, "Death Solves All Problems': The Authoritarian Model of Counterinsurgency," Journal of Strategic Studies, 39, no. 1 (February, 2016), 62-93; Jessica A. Stanton, Violence and Restraint in Civil War: Civilian Targeting in the Shadow of International Law, Kindle Edition (Cambridge University Press, 2016).

${ }^{60}$ Monty Marshall, Keith Jaggers, and Ted Gurr, "Political Regime Characteristics and Transitions, 1800-2016, Polity IV Project” (Dataset Users’ Manual. Center for Systemic Peace, 2017). 
${ }^{61}$ ICIMOD and Central Bureau of Statistics, Nepal, "Mapping Nepal Census Indicators 2001 and Trends" (Kathmandu, December 2003).

${ }^{62}$ ICG, "Nepal's Maoists: Their Aims, Structure and Strategy" (Kathmandu, Nepal: ICG Asia Report Nr 115, 2005), 13, https://www.crisisgroup.org/asia/south-asia/nepal/nepals-maoists-their-aims-structure-and-strategy.

${ }^{63}$ Alexander De Juan and Jan H. Pierskalla, "Manpower to Coerce and Co-opt-State Capacity and Political Violence in Southern Sudan 2006-2010," Conflict Management and Peace Science 32, no. 2 (April 1, 2015): 175-99, doi:10.1177/0738894213520393; Wood, “Opportunities to Kill or Incentives for Restraint?"

${ }^{64}$ ISS, "The Military Balance 1996-2006, South Asia," in The Military Balance 1996, accessed November 24, 2016, http://www.tandfonline.com/doi/pdf/10.1080/04597229608460096?needAccess=true.

${ }^{65}$ Since these sources lack estimates for the first two years, the starting point is taken from Kiyoko Ogura, "Seeking State Power: The Communist Party of Nepal (Maoist)" (Berlin: Berghof Center, 2008), 13. Remaining missing values are linearly interpolated.

${ }^{66}$ Holtermann, "Relative Capacity and the Spread of Rebellion."

${ }^{67}$ This pattern is also pointed out in Joshi and Quinn's (2017) study of the conflict's victims.

${ }^{68}$ Kiyoko Ogura, "Seeking State Power: The Communist Party of Nepal (Maoist)" (Berlin: Berghof Center, 2008); Saferworld, "Policing in Nepal: A Collection of Essays" (London: Saferworld, 2007), 2.

${ }^{69}$ INSEC, "Human Rights Yearbook 1996" (Kathmandu, Nepal, July 1997), 83, 97.

${ }^{70}$ Paul D. Allison and Richard P. Waterman, "Fixed-Effects Negative Binomial Regression Models," Sociological Methodology 32, no. 1 (2002): 247-265. The dispersion parameter from Model 1 is significantly different from zero $(\mathrm{p}<0.000)$.

${ }^{71}$ A. Colin Cameron and Pravin K. Trivedi, Regression Analysis of Count Data, vol. 53 (Cambridge university press, 2013), 354.

72 There is no indication that rebel attacks confounds the association between government attacks and rebel violence: Including several lags of rebel attacks hardly affects the government attacks coefficient.

${ }^{73}$ The VIF values for these variables (1.35 for rebel combatant losses and 1.11 rebel battle losses) do not suggest high collinearity.

${ }^{74}$ SUR accounts for the common error structure of the regressions by combining their results into one parameter vector and simultaneous covariance matrix. StataCorp, "Suest - Seemingly Unrelated Estimation," in Stata 14 Base Reference Manual (College Station, TX: Stata Press, 2015).

${ }^{75}$ Brambor, Thomas, William Roberts Clark, and Matt Golder, "Understanding Interaction Models: Improving Empirical Analyses," Political Analysis 14, no. 1 (2006): 63-82.

${ }^{76}$ Other variables are held at their observed value. The results are broadly similar if each interaction term is added separately. Predictions for more than two government attacks are not graphed because they are less certain.

${ }^{77}$ The full results are found in the Online Appendix (Tables A2 and A3).

${ }^{78}$ The interviews were conducted with the aid of a Nepalese interpreter. Some interviews were not taperecorded, but the author took extensive notes that were checked by the interpreter. Not all quotes are therefore word-for-word transcriptions. I anonymize interviewees who preferred being anonymous or who provided sensitive information. The project is approved by the [country omitted] Data Protection Official for Research.

${ }^{79}$ Anne De Sales, "The Kham Magar Country, Nepal: Between Ethnic Claims and Maoism," European Bulletin of Himalayan Research 19 (2000): 62-63.

${ }^{80}$ Thapa, Ogura, and Pettigrew, "The Social Fabric of the Jelbang Killings, Nepal."

${ }^{81}$ Author's interview with Maoist ex-combatant from Rolpa, December 2011.

${ }^{82}$ Kristine Eck, "Recruitment and Violence in Nepal's Civil War: Microstudies under the Microscope," Asian Survey 58, no. 2 (2018): 276; Marks, Insurgency in Nepal, 14-15.

${ }^{83}$ Prakash Jwala, "Reaping the Whirlwind in Rolpa," Nepali Times, May 3, 2002; Dr Sonal Singh et al.,

"Conflict Induced Internal Displacement in Nepal," Medicine, Conflict and Survival 23, no. 2 (April 1, 2007): 105, doi:10.1080/13623690701248088.

${ }^{84}$ Author's interviews with two Maoist ex-combatant from Rolpa, December 2011, and a civilian Congress supporter from Rolpa, March 2010.

${ }^{85}$ AFP, "Maoists Control Nowhere in Nepal, Army Says, after Report of Rebel HQ Fallen," April 25, 2005.

${ }^{86}$ Author's interviews with two Maoist ex-combatants and a journalist from Rolpa, March 2010.

${ }^{87}$ Author's interview with police officer stationed in Rolpa during the conflict, August 2014.

${ }^{88}$ Thapa, Ogura, and Pettigrew, "The Social Fabric of the Jelbang Killings, Nepal."

${ }^{89}$ Joshi and Pyakurel, "Individual-Level Data on the Victims of Nepal's Civil War, 1996-2006."

${ }^{90}$ Helge Holtermann, "How Can Weak Insurgent Groups Grow? Insights from Nepal," Terrorism and Political Violence 28, no. 2 (2016): 316-337.

${ }^{91}$ Author's interviews with two Maoist ex-combatants and a teacher from Rolpa, March 2010. 
${ }^{92}$ R. Gersony, Sowing the Wind... History and Dynamics of the Maoist Revolt in Nepal's Rapti Hills. (Mercy Corps International, 2003), 73; Ogura, "Maoist People's Governments, 2001-05."

${ }^{93}$ Author's interviews with a Congress activist and a teacher, Doti, April 2010.

${ }^{94}$ Marie Lecomte-Tilouine, “Terror in a Maoist Model Village, Mid-Western Nepal,” Dialectical Anthropology 33, no. 3-4 (2009): 383.

${ }^{9}$ Aditya Adhikari, The Bullet and the Ballot Box: The Story of Nepal's Maoist Revolution (Verso Books, 2014).

${ }^{96}$ Philippe Ramirez, "Maoism in Nepal: Towards a Comparative Perspective," in Himalayan "People"s War': Nepal's Maoist Rebellion, ed. Michael Hutt (London: Hurst, 2004), 236.

${ }^{97}$ Gersony, Sowing the Wind... History and Dynamics of the Maoist Revolt in Nepal's Rapti Hills., 71.

${ }^{98}$ Higher-caste people (Bahuns and Chhetris) constitute 44 percent of civilians killed by rebels, which is higher than their share of the population (ca. 31 percent). However, higher-caste people were also generally overrepresented among the conflict's victims, and constituted 37 percent of civilians killed by state forces. Joshi and Pyakurel, "Individual-Level Data on the Victims of Nepal's Civil War, 1996-2006."

99 Author's interview, Kathmandu, August 2014.

${ }^{100}$ Author's interviews with two Maoist ex-combatants.

${ }^{101}$ Author's interviews with Maoist ex-combatant and Nepali Congress supporter, Rolpa, March 2010.

102 This does not necessarily mean that violence was effective in furthering the Maoists' political aims. Exploring that question is beyond the scope of this study.

${ }^{103}$ Kristine Eck, “Coercion in Rebel Recruitment," Security Studies 23, no. 2 (2014): 388; ICG, "Nepal's Maoists: Their Aims, Structure and Strategy," 14.

${ }^{104}$ CPN-Maoist, "Politbureau Meeting Breaks New Grounds for Revolutionary Practice," Maoist Information Bulletin, October 2003.

${ }^{105}$ See e.g., Max Abrahms, "What Terrorists Really Want: Terrorist Motives and Counterterrorism Strategy," International Security 32, no. 4 (April 1, 2008): 78-105, doi:10.1162/isec.2008.32.4.78; Abrahms and Potter, "Explaining Terrorism"; Humphreys and Weinstein, "Handling and Manhandling Civilians in Civil War"; Jacob N. Shapiro, The Terrorist's Dilemma: Managing Violent Covert Organizations (Princeton, N.J.: Princeton University Press, 2013); Elisabeth Jean Wood, "Armed Groups and Sexual Violence: When Is Wartime Rape Rare?," Politics \& Society 37, no. 1 (2009): 131-161.

${ }^{106}$ Joshi and Pyakurel, "Individual-Level Data on the Victims of Nepal's Civil War, 1996-2006." 